
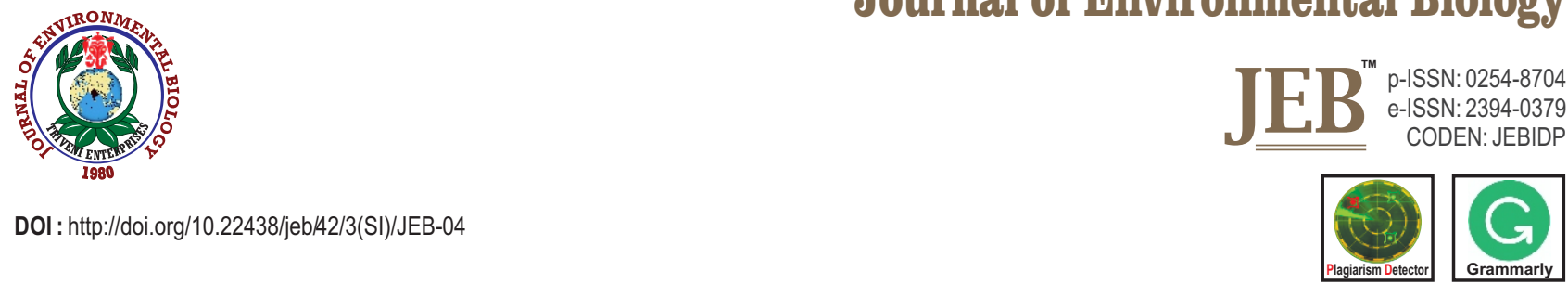

\title{
Decomposition of food waste from protein and carbohydrate sources by black soldier fly larvae, Hermetia illucens L.
}

\author{
N.A.A. Jalii ${ }^{1 *}$, S.H. Abdullah ${ }^{1}$, I.K. Ahmad ${ }^{2}$, N.E.A. Basri' and Z.S. Mohamed ${ }^{2}$ \\ ${ }^{1}$ Department of Earth Science and Environment, Faculty of Science and Technology, Universiti Kebangsaan Malaysia, Bangi, 43600, Malaysia \\ ${ }^{2}$ Department of Civil Engineering, Faculty of Engineering and Built Environment, Universiti Kebangsaan Malaysia, Bangi 43600, Malaysia \\ *Corresponding Author Email : nurulain@ukm.edu.my
}

\section{Abstract}

Aim: To determine the variability of black soldier fly larvae treatment in comparison to different sources of substrates with an emphasis on protein and carbohydrate with regards to black soldier fly larvae growth and the physico-chemical characteristics of the final compost.

Methodology: The study comprised of an experimental setup, sample preparation of synthetic food waste (protein and carbohydrate source), physicochemical and nutrients laboratory test and analysis of data.

Results: The results showed that larvae that compost protein food sources are likely to be bigger than larvae that compost carbohydrate food sources. From the laboratory results, the amount of potassium, phosphorus, magnesium and C/N ratio content of protein source compost were $266.1 \mu \mathrm{g} \mathrm{g}{ }^{-1}, 204.3$

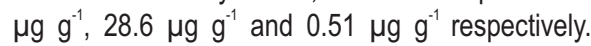
Whereas, the physico-chemical results for the carbohydrate source compost were $55.1 \mu \mathrm{g} \mathrm{g}^{-1}, 20.5$ $\mu \mathrm{g} \mathrm{g}^{-1}, 2.3 \mu \mathrm{gg}^{-1}$ and $3.33 \mu \mathrm{gg}^{-1}$ respectively.

Interpretation: Black soldier fly larvae prefer to accumulate protein food residues rather than carbohydrate food residues, thus emphasizing that protein content is vital for their growth. The increase in potassium, phosphorus and magnesium for black soldier fly larvae yield compost can potentially produce organic solid fertilizer for farming and agricultural industries. The unfavourable nutrients from food waste is considered to be a significant factor that can affect the development, production and efficiency of life stage of composting black soldier fly larvae.

Key words: Black soldier fly larvae, Carbohydrate, Composting, Food waste, Protein

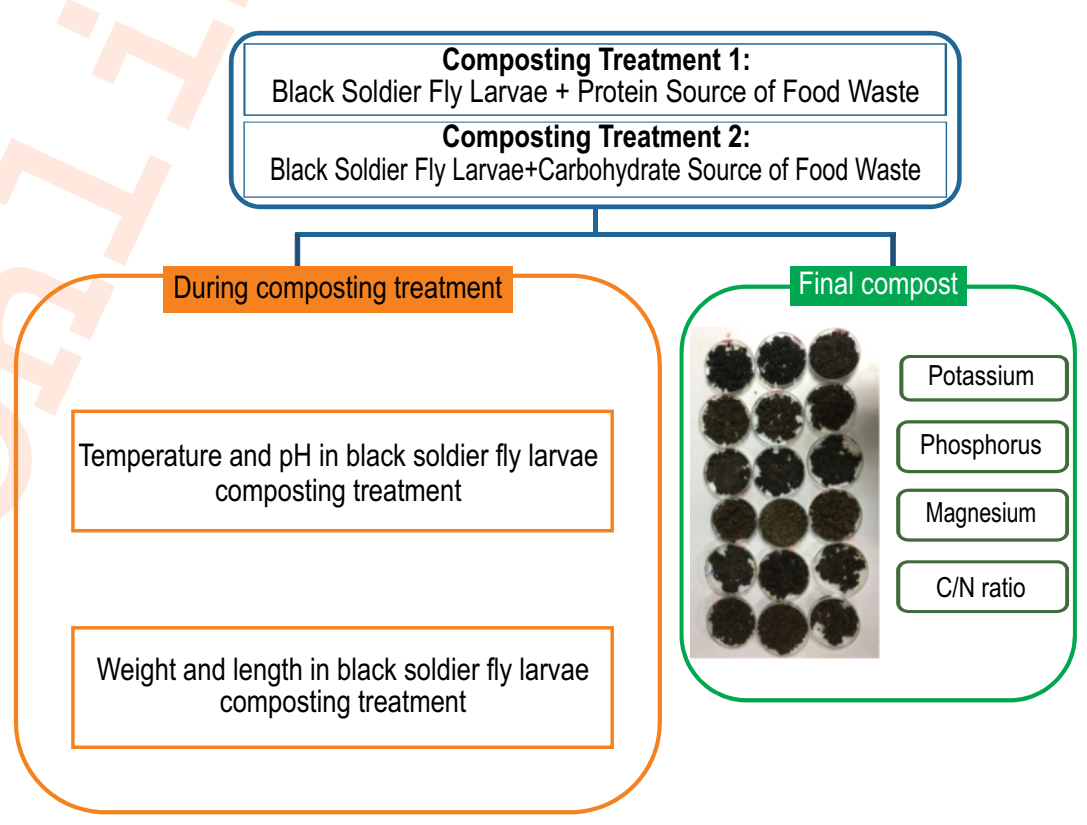

How to cite : Jalil, N.A.A., S.H. Abdullah, I.K. Ahmad, N.E.A. Basri and Z.S. Mohamed: Decomposition of food waste from protein and carbohydrate sources by black soldier fly larvae, Hermetia illucens L. J. Environ. Biol., 42, 756-761 (2021). 


\section{Introduction}

Solid waste management is one of challenges the entire world is facing today, especially in rapidly developing cities (Samsudina et al., 2013). Countries like Malaysia use landfills as their main approach to dispose of their solid waste as it contain large amount of waste and is easier to manage. Malaysia is currently facing the problem of having a high number of unpermitted landfills, and these landfills are not qualified as sanitary landfills (Nurul-Akhma et al., 2012). Besides releasing unpleasant smells, landfill also produce greenhouse gases, leachate and attracting pests and rodents (Cameron et al., 2005). Malaysia is also faces the issue of surpassing the capacity limit for its landfills as many landfills have been closed. The statistics from the Solid Waste Corporation (SWCorp) states that 15,000 tons of food waste is thrown away in Malaysia per day, with 3,000 tons being edible food. (Ghafar, 2017). Organic waste such as food waste in landfills is anaerobic due to lack of oxygen. This anaerobic decomposition produces substantial amount of gasses; approximately 50\% methane and $50 \%$ carbon dioxide, which result in greenhouse gas emissions and contributes to global warming. Methane causes global warming 25 times more than $\mathrm{CO}_{2}$ causes (Qazi et al., 2016). Landfilling represents an inevitable step in any Circular Economy by providing a final sink for waste that is no longer technically or economically valuable residual fractions (Cossu and Stegmann, 2018).

As an alternative to landfills, biological composting methods using black soldier fly larvae is an emerging waste management technology and has become the focus of livestock entrepreneurs because black soldier fly larvae treatment solves the solid waste problem and is also able to generate a decent income with the sale of edible protein and oil resources for animal feed, human utilization and biodiesel production. Furthermore, this approach can help to overcome the solid waste issue by codigesting low-cost food waste with appetizing feeds for black soldier fly larvae (Wong et al., 2020). Rearing black soldier fly is advantageous in controlling the amount of organic waste accumulated as larvae can process a range of feed sources, such as kitchen waste or food waste, animal waste (Nguyen et al., 2015; Lalander et al., 2019; Meneguz et al., 2018) and organic leachates (Popa and Green, 2012). Rehman et al. (2017) emphasized having a proper balance of volatile solid and nitrogen in the black soldier fly larvae substrate. The study found a higher biomass conversion rate when soybean curd residue was mixed with dairy manure compared to when they were separately tested. The experiments evidenced that the mixture has a better nutrient balance $(\mathrm{C} / \mathrm{N})$ in its substrate. Black soldier fly larvae has been found to be able to grow and feed on compost leachate (Popa and Green, 2012). It was also able to eliminate volatile organic acids, nullify its acidity, and intelligently reduce its demand for chemical oxygen. Chen et al. (2017) found that faecal sludge, fowl dung and other organic wastes' moisture content affect the growth and survival rate of the larvae. Mixing cosubstrates with faecal sludge has been reported to enhance larvae feeding (Nyakeri et al., 2019). These larvae can process a variety of organic waste, such as fruits and vegetables including animal remains compared to any other type of flies (Kim et al., 2011; Nguyen et al., 2015). The growth and development rates of black soldier fly are highly influenced by the nutritional content in the organic waste. High-protein and high-fat diets can increase their growth rate and decrease developmental duration (Nguyen et al., 2015). Hence, the composition of black soldier fly larvae's body differs on feeding different substrates, such as their body protein (37.0 to $62.7 \%$ dry matter) and fat content (6.6-39.2\% dry matter) (Barragan-Fonseca et al., 2018). Black soldier fly larvae are able to reduce organic waste up to $80 \%$ (on wet weight basis) (Diener etal., 2015).

The life cycle of a black soldier fly consists of five stages, and the stages are egg, larva, pre-pupa, pupa and adult. The black soldier fly is not classified as a pest because it stays outdoors and has a short life span (Tomberlin et al., 2002). According to Erickson et al. (2004), the black soldier fly larvae do not carry any bacteria or diseases and also have the ability to deactivate Escherichia coli and Salmonella. Once the black soldier fly larvae hatches from its' egg, they immediately start looking for food sources and begin the feeding or decomposition process. The larvae do not sleep or eat constantly. The optimal percentage of humidity for the larvae to undergo decomposition is $60 \%$ to $90 \%$ (Myers et al., 2008). Generally, the females lay eggs second day after mating. Black soldier fly differs from other flies as they are weak flies; they tend to rest on vegetation but not on food sources (Tomberlin and Sheppard, 2002; Čičková et al., 2015). According to Newton et al. (2005), a black soldier fly adult are often be found outdoors on or near livestock, nesting on decaying organic matters like animal waste or plant material. Adult black soldier fly do not eat and only absorb water from damp surfaces to stay hydrated. The challenge encountered with the black soldier fly larvae treatment lies in its variable reliability and productivity when applied to different substrates of waste. In view of the above, the aim of this study was to determine the variability of black soldier fly larvae treatment in comparison to different sources of substrates with an emphasis on protein and carbohydrate with regards to black soldier fly larvae growth and physico-chemical characteristics of final compost.

\section{Materials and Methods}

Experimental setup: The present study was conducted at the Dry Laboratory of Faculty Science and Technology in UKM. A reactor system for black soldier fly larvae was made using plastic containers measuring $30 \mathrm{~cm} \times 30 \mathrm{~cm}$. Square holes were cut on the lids of plastic containers to allow air to flow and a mosquito net was used as a lid to prevent any intrusion (Grossule and Lavagnolo, 2020). The container's lid was designed to ensure the moisture inside the reactor could evaporate easily through the 
holes (Manurung et al., 2016). A company based in Senai, Johor supplied the black soldier fly larvae. Only five to eight-days-old pre-matured larvae were used for this experiment.

Feedstock: Synthetic food waste sample used in this study were mostly food waste in Malaysia. The method of preparation for synthetic sample sources of protein and carbohydrates residues was conducted using cooked chicken meat as a source of protein residue while white rice as the source of carbohydrate residue. Waste food materials were collected from the cafeteria Faculty of Science and Technology. The food samples were grounded and kept in the container of black soldier fly larvae. Coconut husk was used as coating and to maintain moisture in the reactor, while wood residue was used to absorb the odours produced by the food waste so that the sample was not disturbed by other flies and insects. This sample was then replicated into six containers with three containers containing protein and the other 3 containers containing carbohydrate residue. A total of $100 \mathrm{~g}$ of waste sample was placed each of the reactor containers, Reactor $P$ (containing protein source) and Reactor $\mathrm{C}$ (containing carbohydrate source). A total of 200 black soldier fly larvae were assigned to each reactor container. Two control mediums were prepared (one container containing protein sources; one container containing carbohydrate source) for observing the dietary change in the absence of black soldier fly larvae. The duration of this treatment was 10 days.

Physico-chemical and nutrient analysis: The weight and length of black soldier fly larvae was measured every alternate day, beginning from day 1 to day 10 . In this study, 10 larvae were randomly selected for measuring the larval weight and the average readings were used for both food waste categories. Throughout the experiment, the larvae's mass readings were taken and recorded every alternate day until between one and four larvae turned dark, to observe the development stages of larvae. The length of larvae was also measured on alternate days. A total of three larvae were randomly selected for measuring the length. $\mathrm{C} / \mathrm{N}$ ratio test was conducted to determine the ratio of carbon to nitrogen executed based on the standards (ASTM E 777-87 and ASTM E 778-87). This test was carried out on the compost of black soldier fly larvae. Total Organic Carbon (TOC) was used to determine the carbon value, while Kjeldahl method was used to determine the nitrogen content. Potassium, phosphorus and magnesium was determined content in the compost according to ASTM D 8110-17. Inductively coupled plasma mass spectrometry (ICP-MS) was used to determine the potassium, phosphorus and magnesium content.

\section{Results and Discussion}

The temperature of the reactor containing protein and carbohydrate showed a significant increase on third day (Fig. 1a). Due to rapid composting process taking place in the reactor. The increase in temperature was due to the release of $\mathrm{CO}_{2}$ gas by the black soldier fly larvae that were undergoing the process of composting with the food waste. Aerobic composting of sugar in food waste also contributed to the increase in temperature in the reactor (Chang et al., 2008). The temperature of reactor $P$ and reactor $\mathrm{C}$ did not exceed $32^{\circ} \mathrm{C}$ as black soldier fly larvae are mesophilic, which means that the black soldier fly larvae do not favor environmental conditions beyond extreme temperatures (Wong et al., 2001). Temperatures showed a decline trend after fourth day as the black soldier fly larval decomposition process slowed down due to insufficient food.

The $\mathrm{pH}$ of both reactors $\mathrm{P}$ increased during the composting process (Fig. 1b). The $\mathrm{pH}$ value of the reactor control $P$ increased from 6.50 to 7.90 while for reactor $P$, the $\mathrm{pH}$ value increased from 6.42 to 7.61 . Wong et al. (2001) demonstrated that during composting process, ammonia is released through ammonification and organic nitrogen undergoes mineralization which increase the $\mathrm{pH}$ value. Ma et al. (2018) recommends starting bioconversion of organic waste by the black soldier fly larvae at $\mathrm{pH}$ values between 6.0 to 8.0 as it will affect the black soldier fly larvae life span. The $\mathrm{pH}$ value of the reactor close to neutral and slightly basic can be used to repair acidic soil (Huang et al., 2014). The residual carbohydrate food residue for reactor control $\mathrm{C}$ and reactor $\mathrm{C}$ was more acidic as the $\mathrm{pH}$ value decreased. This result is probably due to the production of organic acids from the black soldier fly larvae's gut (Adi et al., 2009). At the end of the experiment, the $\mathrm{pH}$ value of reactor $\mathrm{P}$ shifted to neutral, possibly due to volatilization of ammonia where $\mathrm{H}^{+}$ions were released from the bacterial nitrification process, organic compaction, production of organic and inorganic acids, and the release of carbon dioxide gas during composting process. The increase in $\mathrm{pH}$ value in reactor control $\mathrm{C}$ and reactor $\mathrm{C}$ ranged from 5.40 to 4.84 (Ritika et al., 2015).

It is clear that the black soldier fly larvae in reactor $P$ were larger than the larvae in reactor $C$ (Fig. 2). This indicates that the black soldier fly larvae prefer to decompose food containing proteins. This result is similar to the findings of Nguyen et al. (2015), that the black soldier fly larvae prefer foods high in calories and fat. The moisture in the reactor also plays an important role for BSF larvae to decompose as the sample residue in reactor $C$ dries faster than the residue in reactor $P$. Drying of food waste in reactor $C$ hardens the residual food like rice making it difficult for the black soldier fly larvae to process. Black soldier fly larvae tend to prefer softer feeds (moist) due to their mouth parts that are similar to scavenger insects (Kim et al., 2010; Meneguz et al., 2018). Ventilation is also crucial for composting process as oxygen is required for the black soldier fly larvae to decompose the residue.

The potassium content of the reactor control $P$ and reactor $P$ was $185 \mu \mathrm{g} \mathrm{g}^{-1}$ and $266.1 \mu^{-1} \mathrm{~g} \mathrm{~g}^{-1}$, respectively, while reactor control $C$ and reactor $C$ registered $33.4 \mu \mathrm{g} \mathrm{g}^{-1}$ and $55.1 \mu \mathrm{g}$ $\mathrm{g}^{-1}$ respectively. This showed an increase in potassium content in 

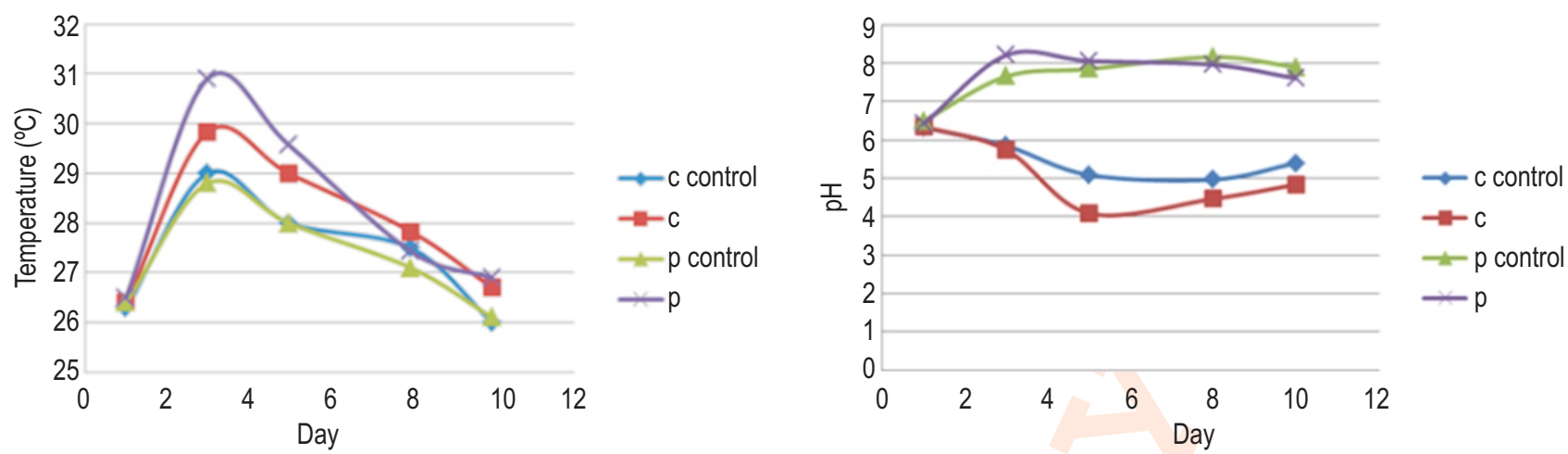

Fig. 1 : (a) Temperature pattern in black soldier fly larvae composting treatment (left); (b) pH pattern in the black soldier fly larvae composting treatment (right).

Table 1: Total temperature, $\mathrm{pH}$, weight and length of BSFL composting treatment

\begin{tabular}{|c|c|c|c|c|c|c|c|c|c|c|c|c|}
\hline \multirow[t]{2}{*}{ Day } & \multicolumn{4}{|c|}{ Temperature $\left({ }^{\circ} \mathrm{C}\right)$} & \multicolumn{4}{|c|}{$\mathrm{pH}$} & \multicolumn{2}{|c|}{ Weight (g) } & \multicolumn{2}{|c|}{ Length $(\mathrm{cm})$} \\
\hline & Pcon & $\mathbf{P}$ & $C$ con & C & Pcon & $\mathbf{P}$ & C con & C & $P$ & C & $\mathbf{P}$ & $C$ \\
\hline 1 & 26.40 & $26.50 \pm 0.01$ & 26.30 & $26.40 \pm 0.01$ & 6.50 & $6.42 \pm 0.01$ & 6.33 & $6.35 \pm 0.01$ & $0.002 \pm 0.001$ & $0.002 \pm 0.001$ & $0.40 \pm 0.01$ & $0.40 \pm 0.01$ \\
\hline 3 & 28.80 & $30.90 \pm 0.10$ & 29.00 & $29.83 \pm 0.47$ & 7.66 & $8.21 \pm 0.05$ & 5.85 & $5.74 \pm 0.22$ & $0.031 \pm 0.003$ & $0.021 \pm 0.005$ & $1.04 \pm 0.10$ & $0.91 \pm 0.07$ \\
\hline 5 & 28.00 & $29.57 \pm 0.49$ & 28.00 & $29.00 \pm 0.10$ & 7.85 & $8.06 \pm 0.12$ & 5.09 & $4.09 \pm 0.03$ & $0.121 \pm 0.009$ & $0.075 \pm 0.005$ & $1.76 \pm 0.02$ & $1.47 \pm 0.03$ \\
\hline 8 & 27.10 & $27.43 \pm 0.05$ & 27.50 & $27.83 \pm 0.15$ & 8.16 & $7.96 \pm 0.16$ & 4.97 & $4.47 \pm 0.18$ & $0.125 \pm 0.010$ & $0.083 \pm 0.005$ & $1.84 \pm 0.06$ & $1.53 \pm 0.17$ \\
\hline 10 & 26.10 & $26.90 \pm 0.05$ & 26.00 & $26.70 \pm 0.05$ & 7.90 & $7.61 \pm 0.12$ & 5.40 & $4.84 \pm 0.24$ & $0.125 \pm 0.003$ & $0.084 \pm 0.001$ & $1.90 \pm 0.03$ & $1.59 \pm 0.05$ \\
\hline
\end{tabular}

$\mathrm{P}=$ Reactor with Protein; $\mathrm{Pcon}=$ Control Reactor with Protein; $\mathrm{C}=$ Reactor with Carbohydrate; Ccon=Control Reactor with Carbohydrate

Table 2: Physico-chemical values of BSFL compost

\begin{tabular}{lllll}
\hline Reactor & Potassium $\left(\boldsymbol{\mu g} \mathbf{g}^{-1}\right)$ & Phosphorus $/\left(\boldsymbol{\mu g ~ g}^{-1}\right)$ & Magnesium $\left(\boldsymbol{\mu g ~ g}{ }^{-1}\right)$ & $\mathrm{C} / \mathrm{N}$ ratio \\
\hline Control protein & 185.0 & 147.0 & 17.6 & 0.38 \\
Protein & $266.1 \pm 19.00$ & $204.3 \pm 20.97$ & $28.6 \pm 3.29$ & $0.51 \pm 0.05$ \\
Control carbohydrate & 33.4 & 18.6 & 5.0 & 5.56 \\
Carbohydrate & $55.1 \pm 10.31$ & $20.5 \pm 1.55$ & $2.3 \pm 0.75$ & $3.33 \pm 1.27$ \\
\hline
\end{tabular}

food waste with the black soldier fly larvae. The phosphorus content also indicated difference between reactor control $P$ and reactor $\mathrm{C}$ compared to $\mathrm{P}$ and reactor $\mathrm{C}$ where the phosphorus content in $\mathrm{P}$ and $\mathrm{C}$ reactants were higher than that of the reactor control $P$ reactants. The phosphorus content in reactor $P$ was $204.3 \mathrm{\mu g} \mathrm{g}^{-1}$ while the content in reactor control $P$ was $147.0 \mathrm{\mu g} \mathrm{g}^{-1}$. However, the magnesium content in reactor $\mathrm{C}$ was lower as compared to reactor control $\mathrm{C}$; the magnesium content in reactor $\mathrm{C}$ was $2.3 \mu \mathrm{g} \mathrm{g}^{-1}$, while reactor control $\mathrm{C}$ registered $5.0 \mu \mathrm{g} \mathrm{g}^{-1}$. The differences in potassium, phosphorus, and magnesium values for reactor control $P$, reactor control $C$, and reactor $P$ and $C$ are due to reaction with methane gas decomposition or mineralization into carbon dioxide. The potassium, phosphorus and magnesium values increased during the composting process may be attributed to concentration impact caused by a faster rate of carbon loss (Lin, 2008). The lower magnesium values may be due to bacteria or microorganisms in reactor $\mathrm{C}$ that use magnesium nutrients during laboratory testing, resulting in lower magnesium values than reactor control C reactants (Jamaluddin et al., 2017).

The $\mathrm{C} / \mathrm{N}$ ratio for the reactor control $\mathrm{P}$ was $0.38,0.51$ for reactor $P, 5.67$ for reactor control $C$ and 3.28 for reactor $C$. Based on the readings, the $\mathrm{C} / \mathrm{N}$ ratio in the reactor control $\mathrm{P}$ was lower than in reactor $\mathrm{P}$, while the condition was different in the reactor control $\mathrm{C}$, with a higher $\mathrm{C} / \mathrm{N}$ ratio than the reactor $\mathrm{C}$. For reactor $\mathrm{P}$, the nitrogen content depleted as some of the nitrogen was released ammonia. The carbon content was lower during decomposition activity of BSF larvae because organic carbon is released $\mathrm{CO}_{2}$. Loss of carbon in the form of $\mathrm{CO}_{2}$ through evaporation during mineralization of organic matter was also demonstrated in the study. For $C$ reactants that exhibit a higher nitrogen content compared to reactor control $C$ reactants, this may be due to the emergence of nitrifying bacteria that emerged during late-phase compaction resulting in higher nitrogen content 


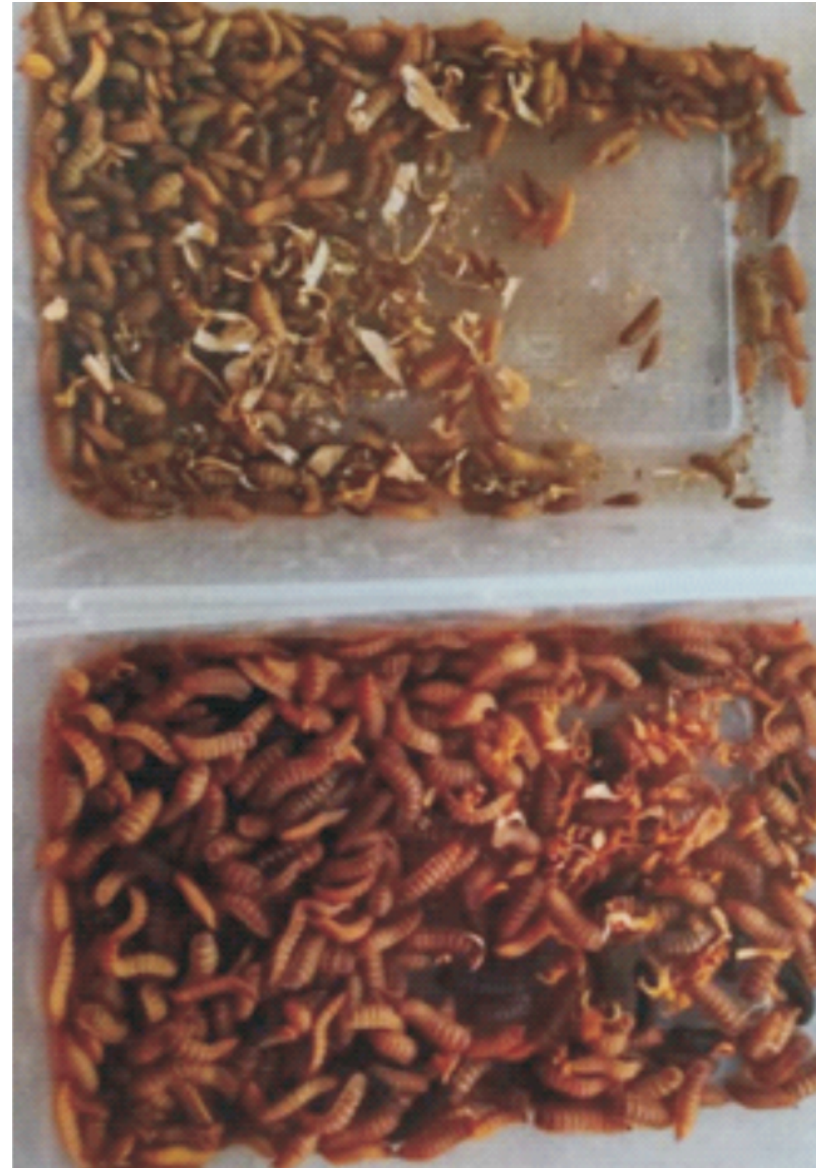

Fig. 2 : Larvae in Reactor C (Top), Larvae in Reactor P (Bottom).

compared to reactor control $\mathrm{C}$ reactants in which no black soldier fly larvae were present (Ritika et al., 2015). A substrate that has large amount of ready carbon and high in protein content for larvae growth is appropriate for the black soldier fly larvae composting (Lalander et al., 2019). The ideal $\mathrm{C} / \mathrm{N}$ ratio is $20: 1$ to 25.1 (Guo et al., 2012). According to Hirai et al. (1983), the ratio of $\mathrm{C} / \mathrm{N}$ cannot be used as an absolute indicator to determine the maturity of compost as the value of good compost is based on the variation of material and characteristics of the material.

From the obtained results, composting of food waste using the black soldier fly larvae indicates that the black soldier fly larvae prefer to accumulate protein food residues rather than carbohydrate food source residues. The nutrient content of substrate or waste is hypothesised to have a major influence on the performance of black soldier fly larvae growth and development (Nguyen et al., 2015). Food waste with high protein content can also increase the larval lipid content, thus emphasising that protein content is crucial for its development. Protein content and amino acids are important elements the black soldier fly larvae to use as animal feeds. The increase in potassium, phosphorus and magnesium for the black soldier fly larvae yield compost can potentially produce organic solid fertilizer for the farming and agricultural industries. In conclusion, unfavourable nutrients from waste is considered to be a significant factor that can affect the development, growth, production and efficiency of the life stage of the composting black soldier fly larvae. Further research should investigate the variability of feeding conversion efficiency and the differential feeding rate of substrate.

\section{Acknowledgments}

This research was financially supported by Universiti Kebangsaan Malaysia, under Grant GGPM-2018-069. We would also like to show our gratitude to Brandon Ooi Kai Yih for the assistance with the laboratory works and data analyses.

\section{Add-on Information}

Authors' contribution : N.A.A. Jalil: Contributed as the corresponding author, came up with the original idea of the study, conducted the study including experiments and manuscript writing; S.H. Abdullah: Contributed in the process of editing manuscripts including updating sentences and language arrangements and finishing tables and figures; I.K. Ahmad, N.E.A. Basri and Z.S. Mohamed: Contributed in providing input in the study and writing of manuscripts.

Research content : The research content of manuscript is original and has not been published elsewhere.

Ethical approval : NotApplicable

Conflict of interest: The authors declare that there is no conflict of interest.

\section{Data from other sources : NotApplicable}

Consent to publish : All authors agree to publish the paper in Journal of Environmental Biology.

\section{References}

Adi, A.J. and Z.M. Noor: Waste recycling: Utilization of coffee grounds and kitchen waste in vermicomposting. Bioresour. Technol., 100, 1027-1030 (2009).

Barragan Fonseca, K.B., M. Dicke and J.J. Van Loon: Influence of larval density and dietary nutrient concentration on performance, body protein, and fat contents of black soldier fly larvae (Hermetia illucens). Entomol. Exp. Appl., 166, $761-770$ (2018).

Cameron, M., J. Marshall, J. Wang and A. Elliot: Human Activity and the Environment, Annual Statistics 2005: Solid Waste in Canada. System of National Accounts, Environment Accounts and Statistics Division, Statistics Canada, Ottawa, Canada, Catalogue no. 16-201-XIE (2005).

Chang, J.I. and T.E. Hsu: Effects of compositions on food waste composting. Bioresour. Technol., 99, 8068-8074 (2008). 
Chen, X., G. Zhao, Y. Zhang, L. Han and W. Xiao: Nitrogen-to-Protein conversion factors for crop residues and animal manure common in China. J. Agric. Food Chem., 65, 9186-9190 (2017).

Cossu, R. and R. Stegmann: Solid Waste Landfilling: Concepts, Processes, Technology. Elsevier, NY, USA, pp.1190 (2018).

Čičková, H., G.L. Newton, R.C. Lacy and M. Kozánek: The use of fly larvae for organic waste treatment. Waste Manage., 35, 68-80 (2015).

Diener, S., C. Lalander, C. Zurbrügg and B. Vinnerås: Opportunities and constraints for medium-scale organic waste treatment with fly larvae composting. In. Proceedings Sardini $2015,15^{\text {th }}$ International Waste Management and Landfill Symposium. CISA Publisher, Italy, pp. 5-9 (2015).

Erickson, M.C., M. Islam, C. Sheppard, J. Liao and M.P. Doyle: Reduction of Escherichia coli 0157:H7 and Salmonella enterica serovar enteritidis in chicken manure by larvae of the black soldier fly. J. Food Prot., 67, 685-690 (2004).

Guo, R., G. Li, T. Jiang, F. Schuchardt, T. Chen, Y. Zhao and Y. Shen: Effect of aeration rate, $\mathrm{C} / \mathrm{N}$ ratio and moisture content on the stability and maturity of compost. Bioresour. Technol., 112, 171$178(2012)$.

Ghafar, S.W.A.: Food Waste in Malaysia: Trends, Current Practices and Key Challenges. FFTC Agricultural Policy Articles, Food Security and Safety, Taipei, Taiwan (2017).

Grossule, V. and M.C. Lavagnolo: The treatment of leachate using black soldier fly (BSF) larvae: Adaptability and resource recovery testing. J. Environ. Manage., 253, 109707 (2020).

Hirai, M.F., V. Chamyasak and H. Kubota: Standard measurement for compost maturity. BioCycle, 24, 54-56 (1983).

Huang, K., F. Li, Y. Wei, X. Fu and X. Chen: Effects of earthworms on physicochemical properties and microbial profiles during vermicomposting of fresh fruit and vegetable wastes. Bioresour. Technol., 170, 45-52 (2014).

Jamaludin, S.N., A.A. Kadir and N.W. Azhari: Study on NPK performance in food waste composting by using agricultural fermentation. MATEC Web Conf., 103, 05015 (2017).

Kim, W.T., S.W. Bae, H.C. Park, K.H. Park, S.B. Lee, Y.C. Choi, S.M. Han and Y.H. Koh: The larval age and mouth morphology of the black soldier fly, Hermetia illucens (Diptera: Stratiomyidae). Int. J. Indust. Entomol., 21, 185-187 (2010)

Kim, W., S. Bae, K. Park, S. Lee, Y. Choi, S. Han and Y. Koh: Biochemical characterization of digestive enzymes in the black soldier fly, Hermetia illucens (Diptera: Stratiomyidae). J. Asia Pac. Entomol., 14, 11-14 (2011).

Lalander, C., S. Diener, C. Zurbrügg and B. Vinnerås: Effects of feedstock on larval development and process efficiency in waste treatment with black soldier fly (Hermetia illucens). J. Clean. Prod., 208, 211-219 (2019).

Lin, C.: A negative-pressure aeration system for composting food wastes. Bioresour. Technol., 99, 7651-7656 (2008).

Ma, J., Y. Lei, K.U. Rehman, Z. Yu, J. Zhang, W. Li, Q. Li, J.K. Tomberlin and L. Zheng: Dynamic effects of initial pH of substrate on biological growth and metamorphosis of black soldier fly (Diptera: Stratiomyidae). Environ. Entomol., 47, 159-165 (2018).

Manurung, R., A. Supriatna, R.R. Esyanthi and R.E. Putra: Bioconversion of rice straw waste by black soldier fly larvae
(Hermetia illucens $L$.): Optimal feed rate for biomass production. J. Entomol. Zool. Stud., 4, 1036-1041 (2016).

Meneguz, M., A. Schiavone, F. Gai, A. Dama, C. Lussiana, M. Renna and L. Gasco: Effect of rearing substrate on growth performance, waste reduction efficiency and chemical composition of black soldier fly (Hermetia illucens) larvae. J. Sci. Food Agric., 98, 57765784 (2018).

Myers, H.M., J.K. Tomberlin, B.D. Lambert and D. Kattes: Development of black soldier fly (Diptera: Stratiomyidae) larvae fed dairy manure. Environ. Entomol., 37, 11-15(2008).

Newton, L., C. Sheppard, D.W. Watson, G. Burtle and R. Dove: Using the Black Soldier Fly, Hermetia illucens, as a Value-Added Tool for the Management of Swine Manure. North Carolina State University. Raleigh, NC, USA(2005)

Nguyen, T.T., J.K. Tomberlin and S.L. Vanlaerhoven: Ability of black soldier fly (Diptera: Stratiomyidae) larvae to recycle food waste. Environ. Entomol., 44, 406-410 (2015).

Nyakeri, E., M. Ayieko, F. Amimo, H. Salum and H. Ogola: An optimal feeding strategy for black soldier fly larvae biomass production and faecal sludge reduction. J. Ins. Food Feed, 5, 201-213 (2019).

Nurul-Akhma, Z., M. Shuhaimi-Othman and M. Azmah: Use of multispecies fresh water biomonitoring to access behavioural changes of Guppy, Poecilia reticulata and freash water prawn, Macrobrachium lanchesteri in response to leachate from landfill. Sains Malays., 41, 573-583 (2012).

Popa, R. and T.R. Green: Using black soldier fly larvae for processing organic leachates. J. Econ. Entomol., 105, 374-378 (2012).

Qazi, W.A., M.H. Azam, U.A. Mehmood, G.A. Al-Mufragi, N.A. Alrawahi and M.F. Abushammala: Quantification of methane emissions from solid waste in Oman using IPCC default methodology. Int. J. Environ. Ecol. Eng., 10, 173-177 (2016)

Rehman, K., A. Rehman, M. Cai, L. Zheng, X. Xiao, A.A. Somroo, H. Wang, W. Li, Z. Yu and J. Zhang: Conversion of mixtures of dairy manure and soybean curd residue by black soldier fly larvae (Hermetia illucens L.). J. Clean. Prod., 154, 366-373 (2017).

Ritika, P., S. Satyawati and P. Rajendra: Study on occurrence of black soldier fly larvae in composting of kitchen waste. IJRBS, 4, 38-45 (2015).

Samsudina, M.D.M. and M.M. Don: Municipal solid waste management in Malaysia: Current practices, challenges and prospect. $\mathrm{J}$. Teknologi, 62, 1293 (2013).

Sheppard, D.C., J.K. Tomberlin, J.A. Joyce, B.C. Kiser and S.M. Sumner: Rearing methods for the black soldier fly (Diptera: Stratiomyidae). J. Med. Entomol., 39, 695-698 (2002).

Tomberlin, J.K., D.C. Sheppard and J.A. Joyce: Selected life-history traits of black soldier flies (Diptera: Stratiomyidae) reared on three artificial diets. Ann. Entomol. Soc. Am., 95, 379-386 (2002).

Wong, C.Y., J.W. Lim, F.K. Chong, M.K. Lam, Y. Uemura, W.N. Tan, M.J. Bashir, S.M. Lam, J.C. Sin and S.S. Lam: Valorization of exomicrobial fermented coconut endosperm waste by black soldier fly larvae for simultaneous biodiesel and protein productions. Environ. Res., 185, 109458 (2020).

Wong, J., K. Mak, N. Chan, A. Lam, M. Fang, L. Zhou, Q. Wu and X. Liao: Co-composting of soybean residues and leaves in Hong Kong. Bioresour. Technol., 76, 99-106 (2001). 